\title{
PRELIMINARY ANALYSIS OF FLOODS INDUCED BY URBAN DEVELOPMENT IN YOGYAKARTA CITY, INDONESIA
}

\author{
Slamet SUPRAYOGI ${ }^{(\mathbb{D})}$, Reviana LATIFAH ${ }^{1}$ (D) and Muh Aris MARFAI ${ }^{\text {*: (D) }}$
}

DOI: $10.21163 /$ GT_2020.152.07

\begin{abstract}
:
The growing population size in the City of Yogyakarta increases the need for settlement and supporting facilities, which consequently expands land-use conversion from previously vacant, productive, and conservative lands to built-up areas. Meanwhile, extensive development means wider impervious surface and gradually narrowing recharge areas, increasing the potential for flooding. This study aimed to analyze the land-use change in the last fourteen years and its relation to runoff coefficients, the maximum discharges occurring with the return periods of 2, 5, 10, and 25 years, and the inundated areas in each return period. The flood inundation was modelled using HEC-RAS. The results showed, in particular, the expansion of the settlement area during the period of 2004-2017. However, such change did not significantly alter the runoff coefficient and, by proxy, the maximum flood discharge. Spatially, the flood scenarios showed overflows from the upper and middle segments of the river.
\end{abstract}

Key-words: urban, flood, HEC-RAS, Indonesia

\section{INTRODUCTION}

The rising number of populations in Indonesia is a major fundamental issue. A high population in urban area can cause new problems, among others, increased needs for settlement. Requiring more spaces for living, human initiates conversion of land utilization from non-residential to settlement areas. In urban development, urbanization (urban feature expansion) is also a cause of land-use conversion (Kodoatie \& Sugianto, 2002). Changes in land functions shrink the number of productive and conservative zones, such as forests and plantations. Decrease in land cover in the form of forest can affect the rise or fall of the discharge value, which in turn affects the extent of inundating water (Dasanto et al, 2014).

Expansion of built-up area and city development broadens the open and impervious surface. As a result, rain falling to the ground transforms into runoff and increases the proportion of surface runoff in the total amount of runoff. The rainfall is an important weather factor because it can increase the quantity of peak flow (Karaoui et al, 2016). The ground no longer has layers that can retain rainwater but immediately turning it into runoff instead. In the case when flow velocity exceeds the infiltration rate, water can neither be absorbed nor appropriately stored (Hadisusanto, 2011). The sprawl of builtup land is proportionally followed by a decrease in the rain catchment area, resulting in a higher potential of flooding. Land-use conversion significantly contributes to the increase in flood quantity and quality (Kodoatie \& Sugianto, 2002).

In the last ten years, the City of Yogyakarta has experienced quite rapid development. It is followed by the accelerated growth of infrastructure (new road networks) (Prayitno, 2018), to support the needs of facilities in the city. This growth expands to the surrounding regions and forms an agglomeration, referred to as the Yogyakarta Urban Agglomeration Area. The increasing density of infrastructures like roads that connect the centers of activities indicates that Yogyakarta is currently developing as the core and point of development according to the spatial concept (Buletin Tata Ruang, 2008). With roads reaching more regions, economic activities multiply as more and more population mobility around their centers is accommodated. An indicator of population mobility is a rise in the population size of Yogyakarta, i.e., around 400,000 inhabitants (BPS Kota Yogyakarta, 2018).

One characteristic of urban physical development is more extensive built-up areas. The growth of the City of Yogyakarta has led to changes in the structure of spatial use. Villages on the outskirts of the city, i.e., Sleman and Bantul Regencies, that provide spaces for shelter have now transformed 
into urban areas (Johnston, 1981; Giyarsih \& Marfai, 2018). Obstacles in developing regions include uncontrolled Building Permit (IMB) that causes constructions to fail to correspond to the principle of water conservation. Multi-story buildings and impervious surfaces in urban areas decrease the chance of rainwater to infiltrate into the soils and, instead, change most of it into surface runoff and even floods. In addition, the lack of ability to manage urban development accompanied by increased climate variability can also be a trigger for flooding (Alvarez \& Resosudarmo, 2019).

Floods occur not only within the city where roads are submerged but also on the banks of the river as well as on floodplain event on the rural area (Gyori et al. 2016). Riverbanks are used for settlements and other types of constructions that involve soil hardening, reducing the capacity of the river to store water and can causing flood (Idham 2018). Drastic human activity can also cause drainage patterns to change (Xie et al, 2017) and decrease the capacity of river channel and river water quality (Suprayogi et al, 2019). Then, water flows faster even when its discharge is unchanged because the cross-section of the river segment narrows. The combination of accelerated flow and exceeded capacity increases the likeliness of intensified erosion on riverbanks. When erosion with faster river flow occurs continuously, buildings on the riverbanks are more prone to collapse.

The state of the art of GIS technology has grown (Goodchild, 2009), and continue to gain important recognition from disaster practitioners and academic researchers. GIS has also been widely used for geographic analysis of flood (Fujiki \& Renand, 2018), for spatio-temporal analysis (Ivan, 2015), to support design and planning on flood protection (Nusi et al. 2019; Al Dianty et al. 2020), and to produce modifications together with other application to visualize flood (Marfai \& Sekaranom, 2015; Tomaszewski, 2015). One of the applications that uses GIS to visualize the results of flood modelling is HEC-RAS. This application is widely used for flood inundation analysis in urban area (Marfai, 2003; Silva et al, 2014; Beretta et al, 2018; Kim et al. 2020)

HEC-RAS is developed for the application of floodplain management and studies that evaluate flood inundation, and it can assess changes in the profiles of riverwater and channel (US Army Coprs of Engineers, 2010a). This application helps to create models and examine hydrological problems and watershed-related issues, specifically floods (US Army Corps of Engineers, 1987). Integrated with the Geographic Information System (GIS) software, it assists users in explaining data spatially. This study aimed to analyze (1) land use in the last fourteen years and its relation to runoff coefficient, (2) the maximum flood discharges occurring with the return periods of 2, 5, 10, and 25 years, and (3) the area of flood inundation for each return period.

\section{METHODS}

\subsection{Research area}

This research was carried out in Winongo Watershed, which administratively includes seven districts, namely Turi, Pakem, Sleman, Ngaglik, Mlati, Gamping, and Tegalrejo. As for the flood inundation scenario, it used a segment of the Winongo River that traverse five districts in the City of Yogyakarta, which are Tegalrejo, Jetis, Gedongtengah, Wirobrajan, and Ngampil. This research area id presented in Fig. 1. This river segment was selected because it is located in an urban area with the rapid growth of urban housing. Meanwhile, the drainage system is natural, i.e., rivers and tributaries. Rivers are the primary system that receives rainwater and wastewater from secondary and tertiary channels, triggering flood problems in the study area, particularly overflows to urban settlements and roads.

\subsection{Material and equipment}

The study employed field observations for spatial analysis, and the required data were as follows: Quickbird imagery for land cover analysis on a detailed scale, the Indonesian Topographic Maps (RBI), land use map, soil map, time-series rain data, and drainage network map. Meanwhile, the tools and instruments used were GPS, Abney levels, measuring tapes, ranging rods, digital cameras, personal computers, and stationery, as well as distometer and uncrewed aerial vehicles to create DEM. 


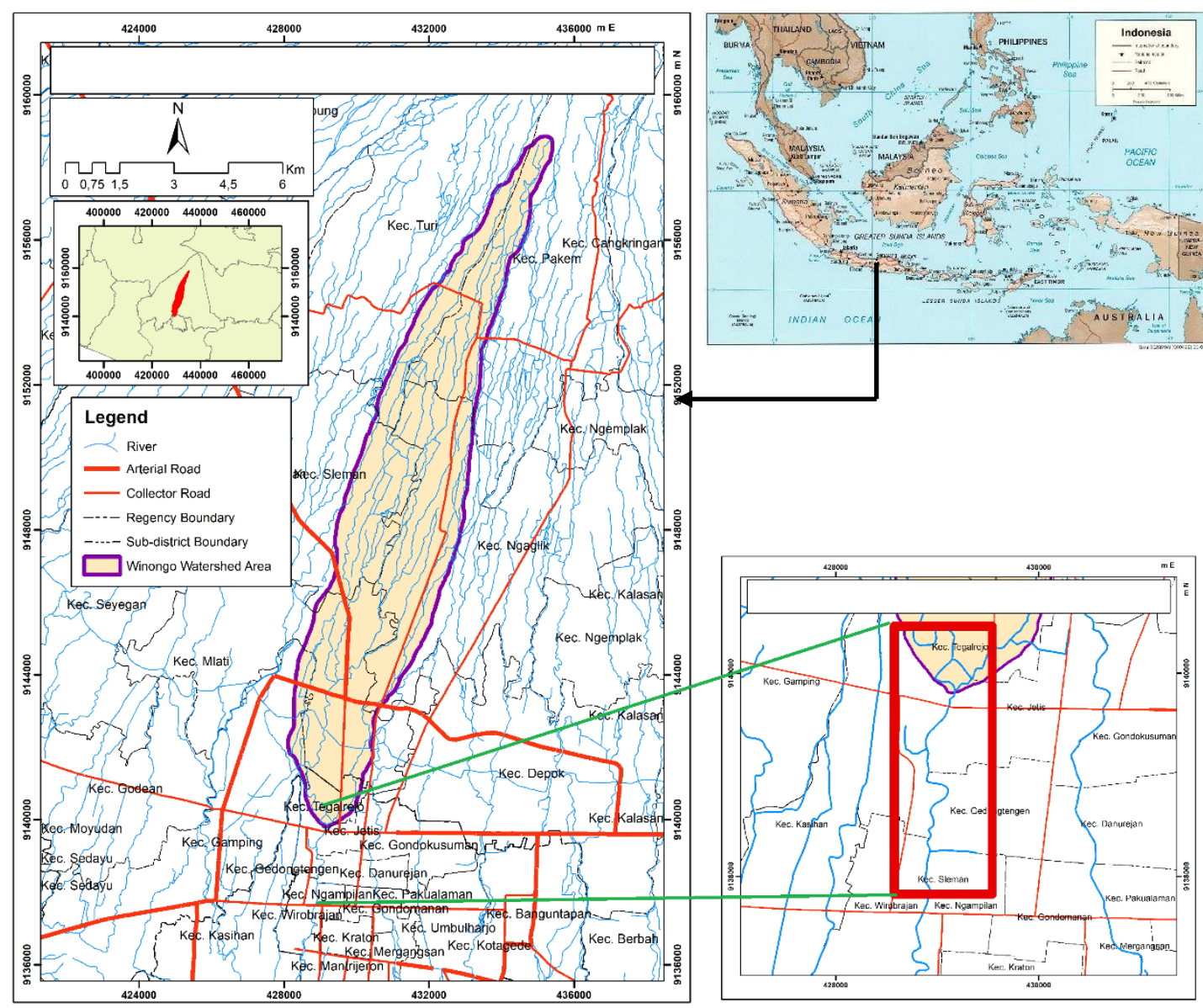

Fig. 1. The map of research area

\subsection{Procedure}

Flood inundation scenario or modelling was created in HEC-RAS and ArcGIS software using riverflow data, river geometry, and Manning's roughness coefficient as the parameters (US Army Corps of Engineers, 2010b). However, due to limited data on river flow, the rational method was used to estimate the maximum discharge (flood peak) (Kusumastuti et al, 2019). Spatially, the river geometry was obtained through mathematical calculations on DEM derived from elevation data. The Manning's coefficient of roughness was determined at each cross-section on each channel (Arcement and Schneider, 1989), namely the left overbank, main channel, and right overbank. The modelled or simulated flood inundations were displayed in ArcGIS software to identify the location and distribution of flooding spatially.

\section{- Maximum discharge calculation}

The rational method is widely used to calculate peak flow (Chin, 2019). The formula used to estimate the maximum discharge was that of the rational method, which is:

$$
Q=0,278 \text { C I A }
$$


Notes:

Q : the peak discharge of surface runoff $\left(\mathrm{m}^{3} / \mathrm{s}\right)$

C : runoff coefficient (dimensionless)

A : area of drainage basin $\left(\mathrm{Km}^{2}\right)$

$\mathrm{I}$ : rainfall intensity (mm/hour)

The runoff coefficient (C) was based on the Cook's method (Miller, 1984) i.e., by calculating the weight of the overlaid layers of land use, soil, relief (slope gradient), and surface storage. In this study, the surface storage was computed by the flow density approach. As for the rainfall intensity, it was estimated using the formula $I=\frac{P 24}{24}\left(\frac{24}{T c}\right)^{\frac{2}{3}}$ where P24 is 24-hour rainfall (mm) and Tc is the time of concentration (in hour, based on the Kirpich's method) (Suripin, 2002). Rainfall was estimated from predicting recurrent maximum precipitation for the return periods of $2,5,10$, and 25 years in the Rainbow software. From this rainfall data, the maximum discharge for each return period was derived.

- $\quad$ River geometry data

The geometric features of a river can be spatially described in HEC-GeoRAS, which shows river network and elevation data in the TIN format. There are four geometric components, namely stream centerlines, bank lines, flow path centerlines, and XS Cross Section. Stream centerlines were used as a reference for creating bank lines, flow path centerlines, and XS Cross Section. XS Cross Section, a line traversing the river flow, was used to determine the condition of the river cross-sections produced in the TIN extraction process. The geometric components of the river are presented in Fig. 2.
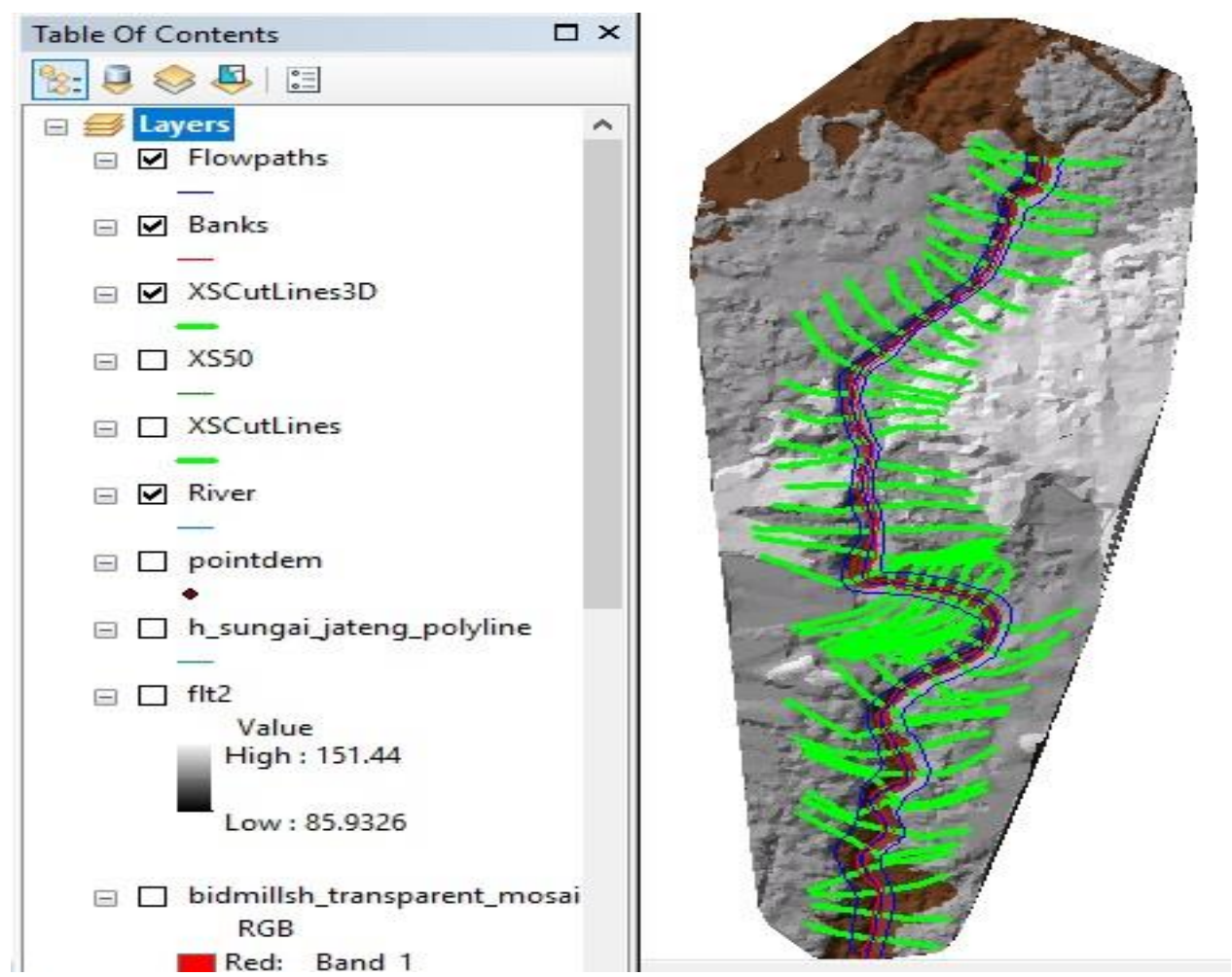

Fig. 2. The visual description of river geometry in HEC-GeoRAS

(Source: US Army Coprs of Engineers, 2010a) 


\section{RESULTS AND DISCUSSION}

\subsection{Physical Condition}

The soil in the study area is composed of volcanic deposits, deposits of clay, clay-sand, sand, and gravel, and dacitic tuffs. Based on the spatial distribution, clay and sand deposits are dominant. In terms of responses to rainwater, a more porous soil absorbs higher rainwater volume. Therefore, compared with clay, sandy soils absorb water faster and store a more significant amount of water.

Flow velocity is influenced by the slope and roughness of the surface (frictions) on which water flows (Govers et al. 2000). Topography (slope) plays a role in modifying the speed and volume of river flow. Higher slope gradient reduces the capacity of soil to absorb rainwater and, instead, it transforms more portions of it into surface runoff that accumulates in the river body. In the study area, the slope ranged between 0.0097-10.26\% with high slope gradients identified in Turi and Pakem Districts; then, it gradually flattened from the middle to the lower part of the watershed.

Winongo Watershed is mainly used for irrigated rice fields and settlements. The study found land-use conversions between the year 2004 and 2017. The increased residential areas in the City of Yogyakarta is attributable to educational activities, which are believed to have triggered urbanization and urban development (Rachmawati et al, 2004). A higher density of settlement means a broader impervious surface that contributes to transforming more proportion of rainfall into surface runoff. This is consistent with previous research, that urban areas will affect the infiltration process. The waterproof surfaces will worsen the runoff process because the dynamics of the infiltration process area disrupted (McGrane, 2016). The land-use change in Winongo Watershed is presented in Table 1. Spatially, the densely populated residential areas in the downstream, i.e., close to the city, had significantly expanded in 2017. The 2004 and 2017 land use maps are illustrated in Fig. 3.

Table 1.

The land utilization of Winongo Watershed in 2004 and 2017

\begin{tabular}{|l|c|c|c|c|}
\hline \multirow{2}{*}{\multicolumn{1}{c|}{ Land use }} & \multicolumn{4}{|c|}{ Area $\left(\mathbf{K m}^{\mathbf{2}}\right)$} \\
\cline { 2 - 5 } & $\mathbf{2 0 0 4}$ & $\mathbf{\%}$ & $\mathbf{2 0 1 7}$ & \% \\
\hline Shrubs & 0.11 & 0.26 & 0.109 & 0.26 \\
\hline Building & 0.04 & 0.10 & 0.254 & 0.60 \\
\hline Plantation & 2.05 & 4.81 & 2.379 & 5.58 \\
\hline Settlement & 12.47 & 29.22 & 15.239 & 35.72 \\
\hline Grass & 0.34 & 0.80 & 0.337 & 0.79 \\
\hline Rice field & 26.73 & 62.65 & 23.391 & 54.83 \\
\hline Dry agricultural land & 0.93 & 2.17 & 0.829 & 1.94 \\
\hline Industrial area & - & 0 & 0.123 & 0.29 \\
\hline Total & 42.661 & 100.00 & 42.661 & 100.00 \\
\hline
\end{tabular}

Land use with increased areas included buildings, plantations, settlements, and industrial zones. These four types of land use are closely related to human activities. Expansion of buildings, residential areas, and industrial estates is an effort to improve urban facilities due to urban development. Meanwhile, a decrease in vacant land covered by shrublands and grass, as well as irrigated rice fields and dry agricultural lands with productive soils, confirms that the land-use conversion in Winongo Watershed is oriented to built-up areas. Moreover, abandoned spacefaring of many factors attracting developers to build houses in the city (Suradi \& Bakti, 2004). 

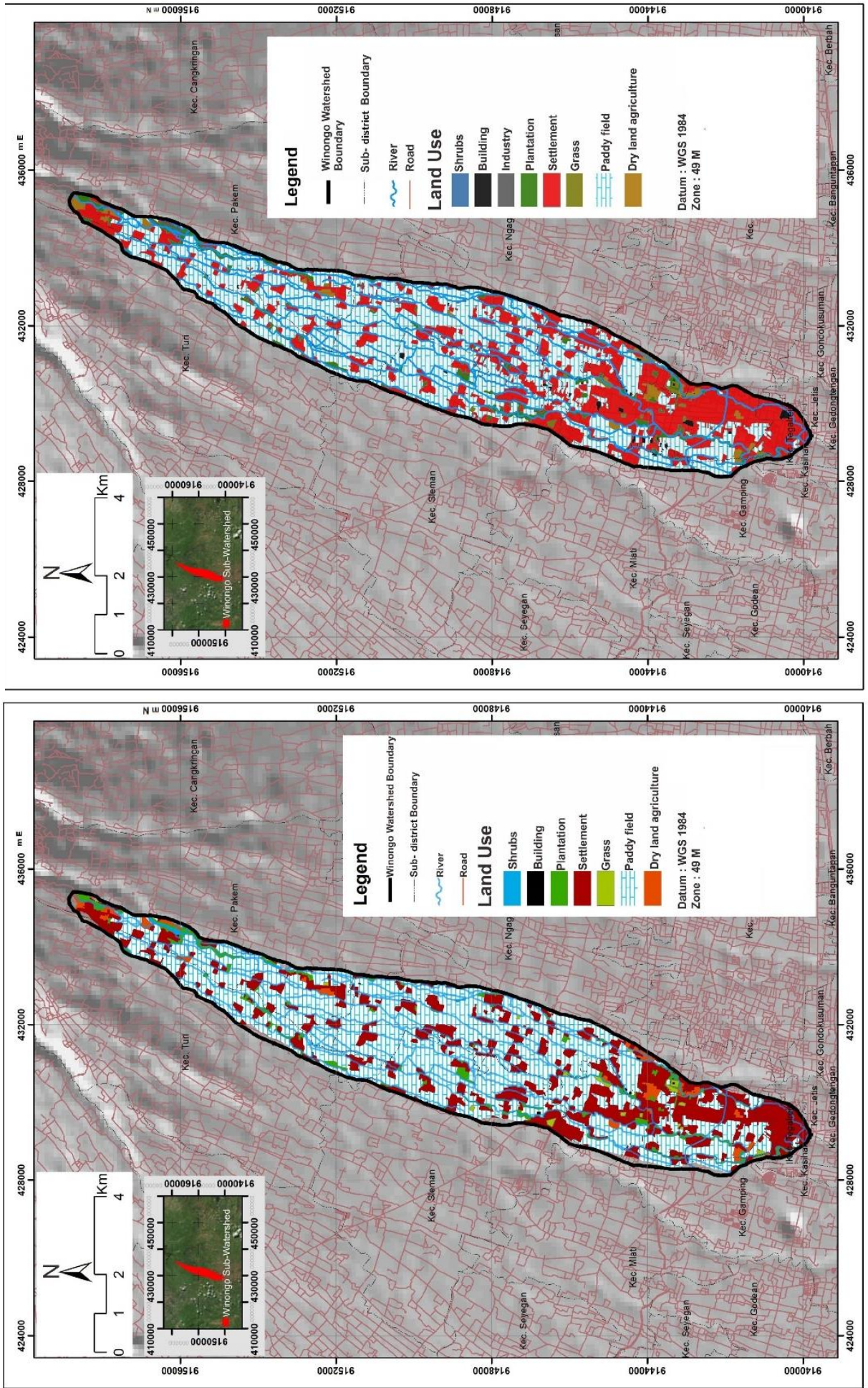

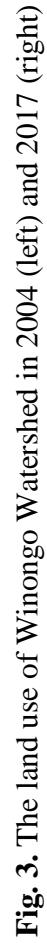

Recurrent rainfall was estimated using 15-year series of rain data at five weather stations, namely Angin-Angin, Beran, Gemawang, Kemput, and Prumpun. The software calculation resulted in rainfall 
data with the return periods of 2, 5, 10, 25, and 50 years. Afterward, Intensity Duration Curve Frequency (IDF) was developed to obtain rainfall intensity based on time of concentration, as presented in Fig. 4.

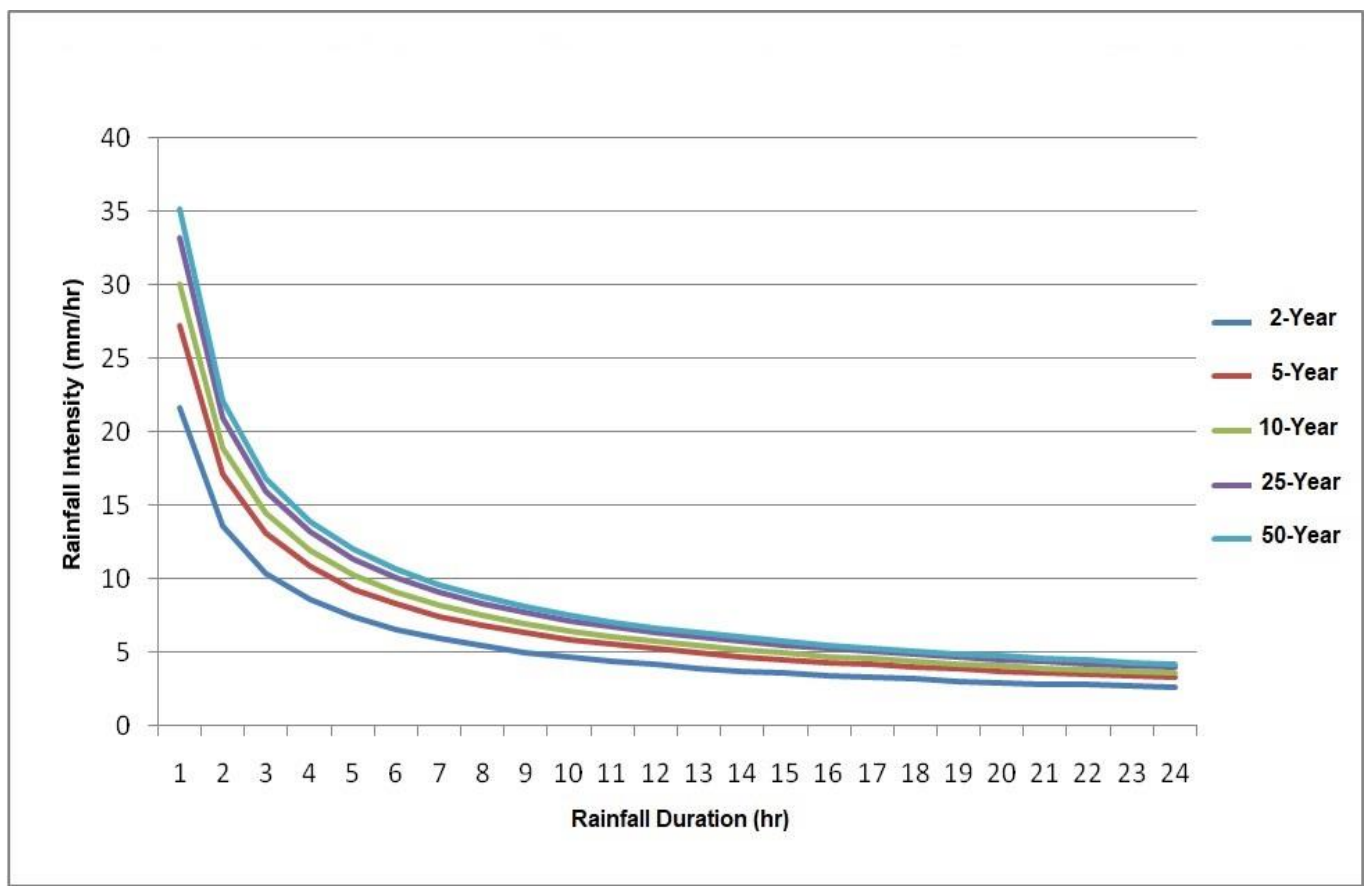

Fig. 4. Rainfall intensity-duration-frequency curves based on time of concentration.

\subsection{Runoff coefficient}

The runoff coefficient shows the ratio of surface runoff to rainfall, with values ranging from 0 to 1. A smaller coefficient (approaching 0) indicates that an area stores a portion of rainwater falling to it, whereas a larger one (closer to 1) shows that an area has less ability to store rainwater properly and tends to transform it into runoffs. Cook's methodconfirmed that the land-use conversion from the year 2004 to 2017 did not change the runoff coefficient drastically. The runoff coefficients in both years were similar, i.e., the weighted average in 2004 was 0.64 and slightly increased to 0.652 in 2017 .

\subsection{Maximum flood discharge}

The maximum flood discharge calculated by the Rational method is presented in Table 2 . The characteristics of a watershed are relatively static, except for land use that tends to be dynamic. Therefore, parameter C (runoff coefficient) in 2004 was different from the one in 2017, and it represents how land use has changed in fourteen years. Meanwhile, the rainfall intensity and area of drainage basin incorporated in the calculation were unchanged. High rainfall intensity and concomitant extreme runoff can lead to flooding in urban areas (Jha et al. 2012). The rainfall intensities of Winongo Watershed for each return period were as follows: $16.5 \mathrm{~mm} /$ hour for the 2year return period, $20.8 \mathrm{~mm} /$ hour for 5 -year, $23.0 \mathrm{~mm} /$ hour for 10 -year, and $25.3 \mathrm{~mm} /$ hour for 25 year. This watershed covers an area of $42.66 \mathrm{Km} 2$. 
Table 2.

The estimation of maximum flood discharge (in $\mathrm{m}^{3} / \mathrm{sec}$ ) in 2004 and 2017

\begin{tabular}{|c|c|c|c|c|c|c|c|c|}
\hline \multirow{2}{*}{$\begin{array}{c}\text { Return Period } \\
\text { (Year) }\end{array}$} & \multicolumn{4}{|c|}{ 2004 } & \multicolumn{5}{c|}{2017} \\
\cline { 2 - 8 } & C & I & A & Q & C & I & A & Q \\
\hline 2 & 0.640 & 16.5 & 42.66 & 127.3 & 0.652 & 16.5 & 42.66 & 127.9 \\
\hline 5 & 0.640 & 20.8 & 42.66 & 157.9 & 0.652 & 20.8 & 42.66 & 160.5 \\
\hline 10 & 0.640 & 23.0 & 42.66 & 174.6 & 0.652 & 23.0 & 42.66 & 177.6 \\
\hline 25 & 0.640 & 25.3 & 42.66 & 192.0 & 0.652 & 25.3 & 42.66 & 195.7 \\
\hline
\end{tabular}

From 2004 to 2017, changes in land use did not significantly affect the maximum flood discharge for the 2-year return period, with a difference of merely $0.6 \mathrm{~m}^{3} / \mathrm{s}$. However, for the 5-, 10-, and 25 year return periods, the differences were noticeable, i.e., $2.6 \mathrm{~m}^{3} / \mathrm{s}, 3.0 \mathrm{~m}^{3} / \mathrm{s}$, and $3.7 \mathrm{~m}^{3} / \mathrm{s}$, respectively. The longer the recurrence intervals, the higher the maximum discharge and the more extensive the flood inundation are.

\subsection{Flood inundation analysis}

The stream centerlines generated from HEC-GeoRAS were $2.12 \mathrm{~km}$ in length. Referring to Marfai (2003), this study concluded that there were two types of channel surfaces. Since meandering channels with clear water were dominant in Winongo River, its Manning's coefficient of roughness was $n=0.04$. Also, the presence of dams and buildings on both right and left floodplains categorized the coefficient of roughness at $n=0.013$. The terrain along the river varied, and there were even river segments with terraced cliffs and crags.

The modeling using elevation data, as derived from aerial photographs, produced an acceptable accuracy, with recommended minor corrections on points of elevation that were distorted due to the high densities of vegetation and built-up land in the study area. The HEC-GeoRAS modeling generated a pattern of flood inundation scenarios that were similar for each return period and runoff coefficient in 2004 and 2017. In general, the eight models (four return periods each in 2004 and 2017) showed that several river segments could not accommodate the maximum discharge and, therefore, caused overflows. Spatially, these segments are located in the upper and middle parts of the river. Settlements and buildings were land utilizations that regularly suffered losses due to flood inundation for the return periods of 2,5 , and 10 years because these forms of human occupation were built close to the river, particularly on the riverbanks. Meanwhile, for the 25-year return period, the area of inundation was broader and even reached several cemeteries.

Compared to the year 2004, the simulated floods in 2017 inundated a more extensive area but with less noticeable change. This condition was caused by the conversion of land use in the last fourteen years, which likely led to increased runoff coefficient and, subsequently, maximum discharge. The inundated area for the 2-year return period was $7,131.1 \mathrm{~m}^{2}$ in 2004 and expanded to $7,178.1 \mathrm{~m}^{2}$ in 2017.For the 5-year return period, the modeled maximum discharge inundated 7,461.7 $\mathrm{m}^{2}$ land in 2004 and broadened to $7,498.8 \mathrm{~m}^{2}$ in 2017. As for the return period of 10 years, the inundated area increased from $7,977.8 \mathrm{~m}^{2}$ in 2004 to $8,017.8 \mathrm{~m}^{2}$ in 2017 . The same case applies to the maximum discharge with a 25-year return period, which inundated 8,649.7 $\mathrm{m}^{2}$ in 2004 and up to $8,844.4 \mathrm{~m}^{2}$ in 2017. The spatial distributions of flood inundation based on land use in 2004 and 2017 are presented in Fig. 5, 6, 7 and 8 each for maximum flood discharge with the return period of 2, 5, 10 , and 25 years. 

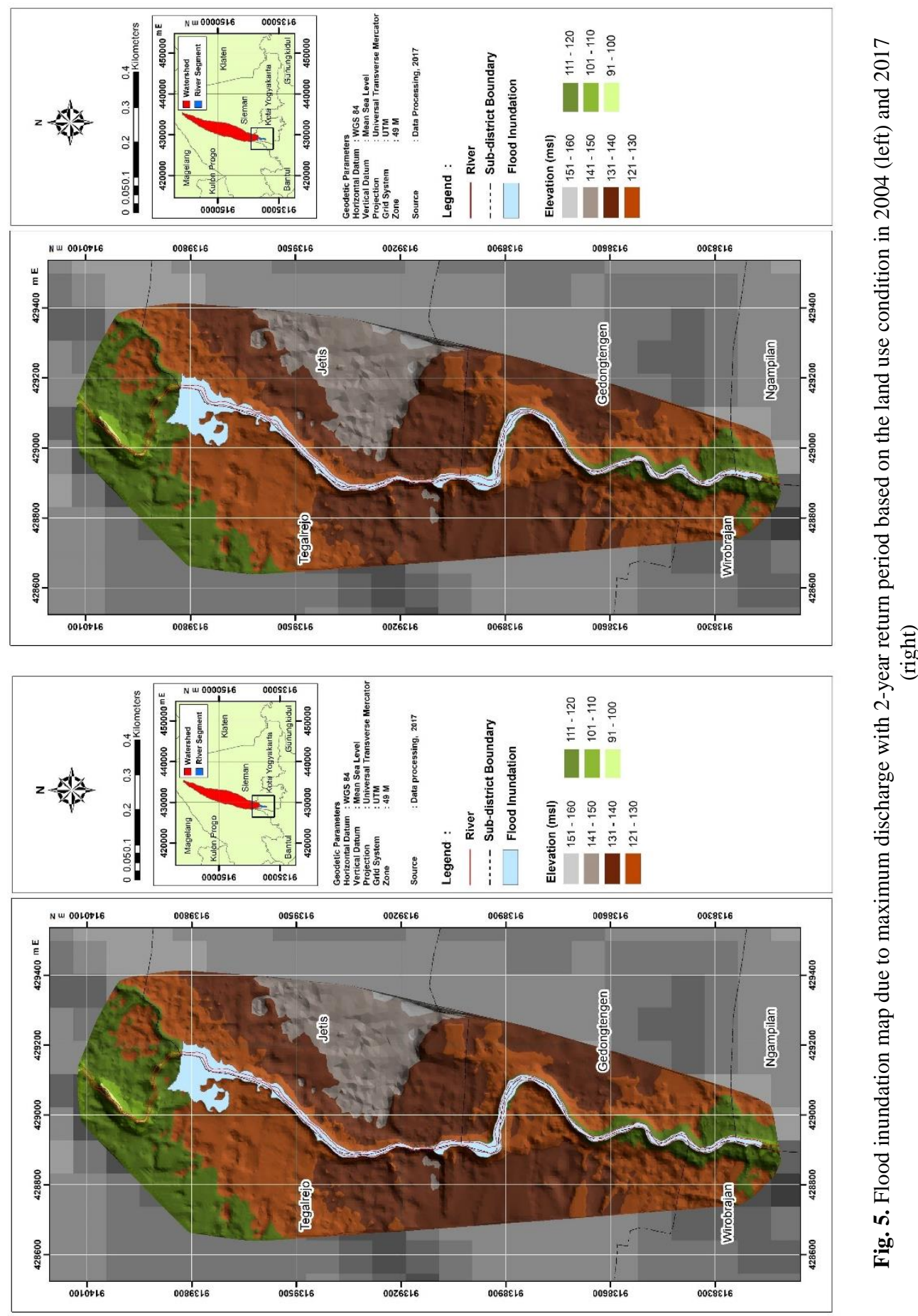


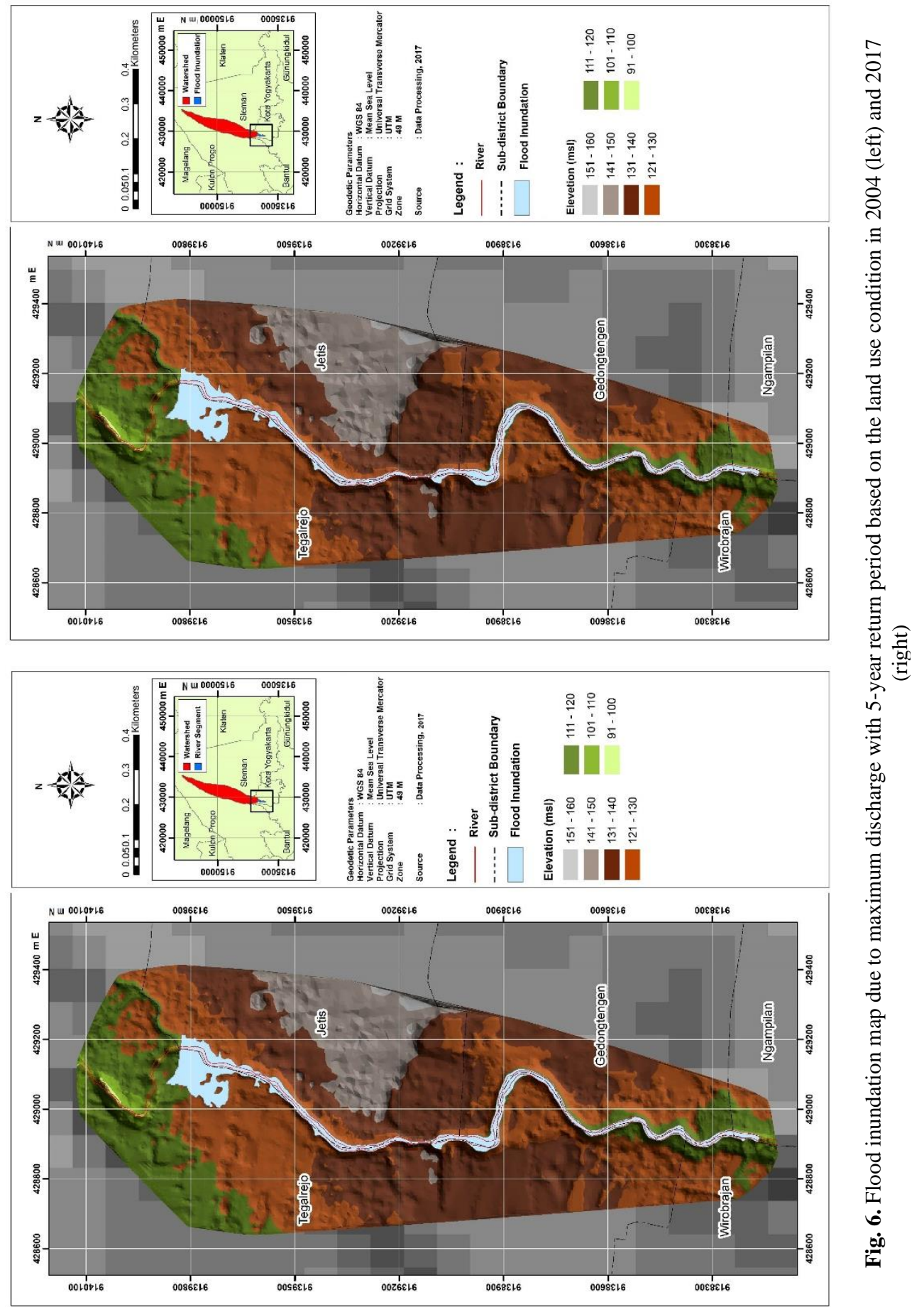



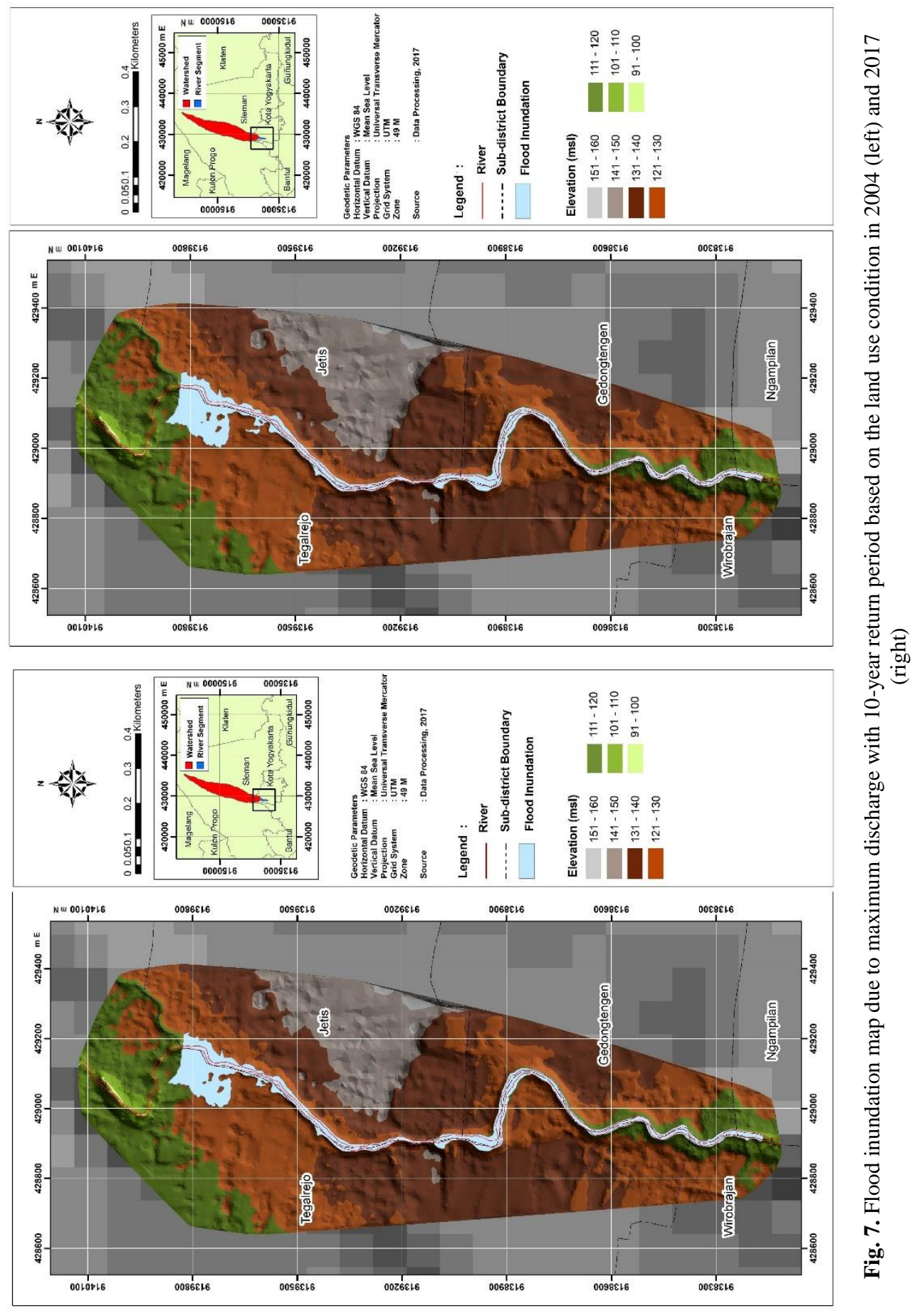


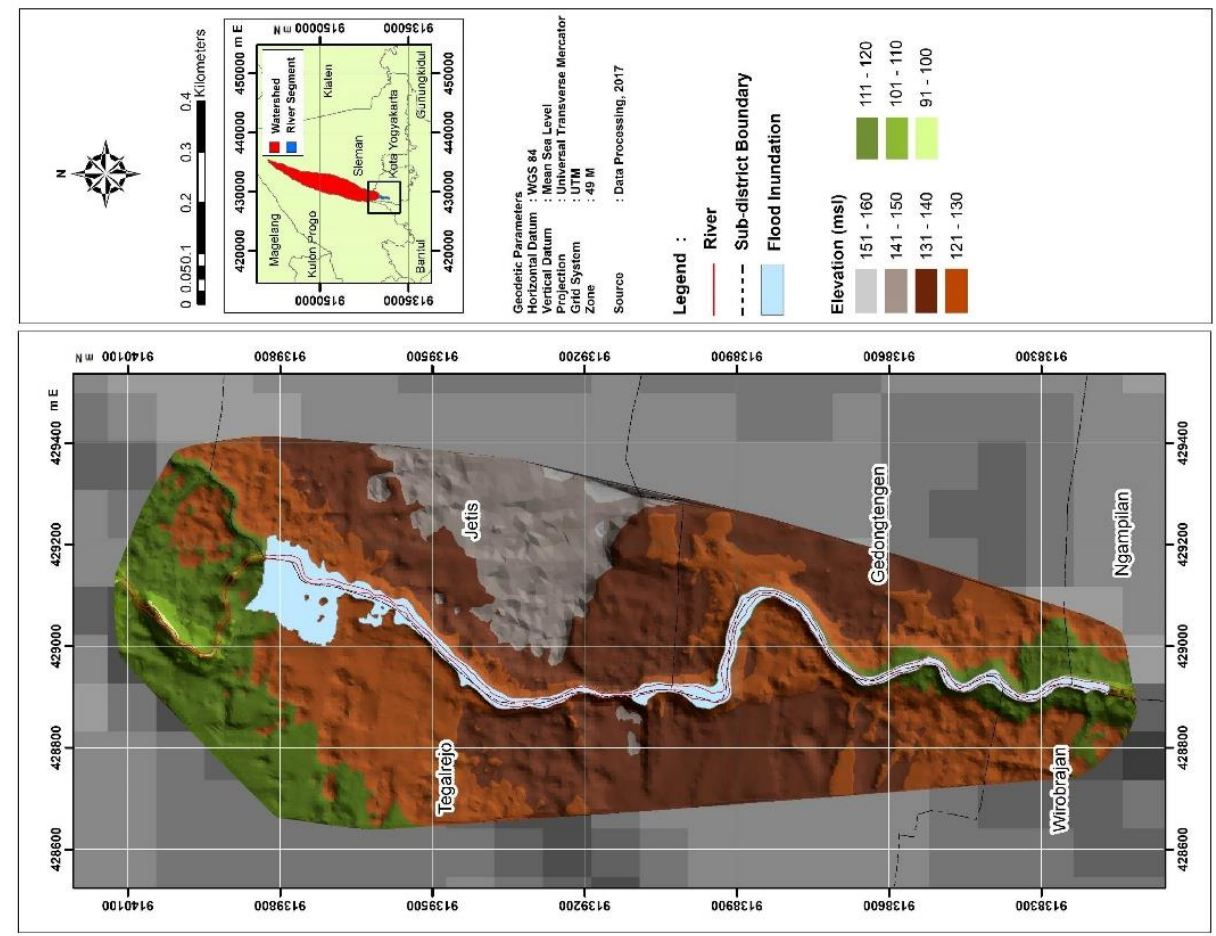

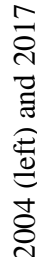

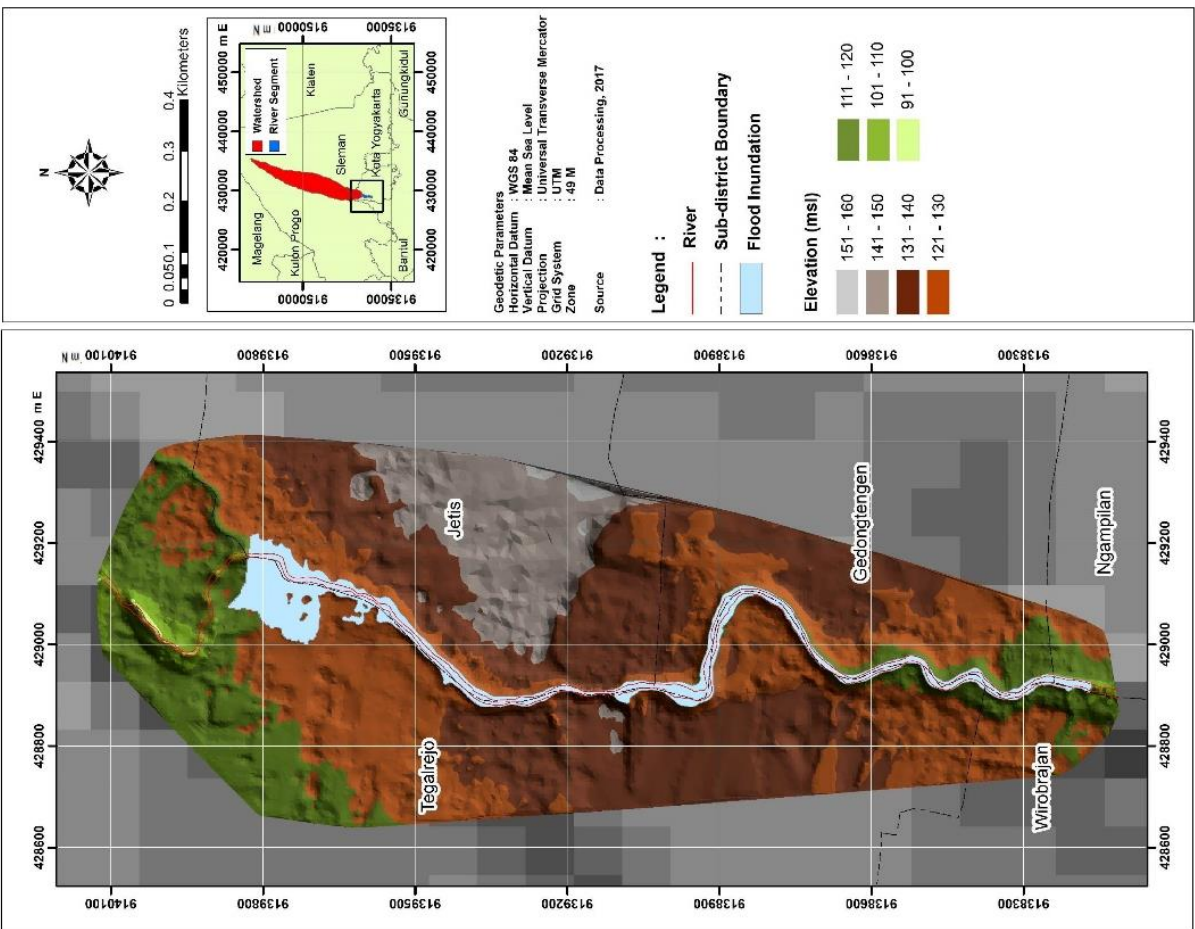




\section{CONCLUSION}

Land-use conversion, as seen in the last fourteen years from 2004 to 2017, is the consequence of urban development in Winongo Watershed. It causes an increase in built-up areas (i.e., settlements, buildings, industrial zone) and a decrease in vacant land (i.e., shrubs, grass) and productive land (i.e., irrigated rice fields and dry agricultural land). As a result, the runoff coefficients changed from 0.64 in 2004 to 0.652 in 2017. Although insignificant, such difference has led to varying changes in maximum river flow discharge. In 2014, the maximum discharge with a 2-year return period was $127.3 \mathrm{~m}^{3} / \mathrm{s}$ and slightly increased to $127.9 \mathrm{~m}^{3} / \mathrm{s}$ in 2017 . However, for the 5-, 10-, and 25-year return periods, there were noticeable rises in maximum discharge. The model for a 5-year return period showed an increase from $157.9 \mathrm{~m}^{3} / \mathrm{s}$ (in 2004) to $160.5 \mathrm{~m}^{3} / \mathrm{s}$ (in 2017). For the 10-year return period, the maximum discharge rose from $174.6 \mathrm{~m}^{3} / \mathrm{s}$ (in 2004) to $177.6 \mathrm{~m}^{3} / \mathrm{s}$ (in 2017), and for the 25 -year return period, it also increased from $192.0 \mathrm{~m}^{3} / \mathrm{s}$ (in 2004) to $195.7 \mathrm{~m}^{3} / \mathrm{s}$ (in 2017). Furthermore, the areas of flood inundation for each return period $\left(2,5,10\right.$, and 25 years) were respectively: $7,131.1 \mathrm{~m}^{2}$ (2004) and 7,178.1 $\mathrm{m}^{2}$ (2017); 7,461.7 $\mathrm{m}^{2}$ (in 2004) and 7,498.8 $\mathrm{m}^{2}$ (in 2017); 7,977.8 $\mathrm{m}^{2}$ (in 2004) and $8,017.8 \mathrm{~m}^{2}$ (in 2017); 8,649.7 $\mathrm{m}^{2}$ (in 2004) and 8,844.4 $\mathrm{m}^{2}$ (in 2017). As preliminary, this analysis shown that spatially, the overflows and floods have been identified in the upper and middle segments of the Winongo River. More elaborative research including the governance in disaster management is necessary to be done in the near future.

\section{ACKNOWLEDGEMENTS}

Part of the process has been supported by faculty of geography, Universitas Gadjah Mada. Author would also like to thank the entire parties who have contributed to this research, both in funding or collecting and processing data.

\section{R E F E R E N C E S}

Alvarez, J. A. C. \& Resosudarmo, B. P. (2019) The cost of floods in developing countries' megacities: a hedonic price analysis of the Jakarta housing market, Indonesia. Environmental Economis and Policy Studies, 21, 555-577.

Al Dianty M., Arbaningrum, R., Putuhena, F.J. (2020) The linkage of effect climate change for determining design flood of Tenggang river. Geographia Technica, 15, Special Issue, 3-12. DOI:10.21163/GT_2020.151.17

Arcement, G. J. \& Schneider, V.R. (1989) Guide for Selecting Manning's Roughness Coefficients for Natural Channel and Flood Pains Available from: https://pubs.usgs.gov/wsp/2339/report.pdf [Accessed 14th November 2019].

Beretta, R., Ravazzani, G., Maiorano, C. \& Mancini, M. (2018) Simulating the Influence of Buildings on Flood Inundation in Urban Areas. Journal of Geosciences MDPI, 8 (77).

Booker, A. S. (2006) Modeling the 100-Year Flood Using GIS: A Flood Analysis in the Avon Park Watershed. Graduate Theses and Dissertations, University of South Florida.

BPS Kota Yogyakarta (2018) Kota Yogyakarta dalam Angka 2018. Yogyakarta: BPS Kota Yogyakarta.

Buletin Tata Ruang (2008) Kawasan Aglomerasi Perkotaan YOGYAKARTA dan Trans Jogya. 
Chin, D. A. (2019) Estimating Peak Runoff Rates Using the Rational Method. Journal of Irrigation and Drainage Engineering, 145.

Dasanto, B. D., Pramudya, B., Boer \& Suharnoto, Y. (2014) Effects of Forest Cover Change on Flood Characteristics in the Upper Citarum Watershed. Jurnal Manajemen Hutan Tropika (JMHT), 10 (3), 141 149.

Fujiki, K., Renard F. (2018) A geographic analysis of post-disaster social impacts on a municipal scale - a case study of a potential major flood in the Paris region (France). Geographia Technica, 13 (2), 31-51. DOI : 10.21163/GT_2018.132.03

Giyarsih, S.R. \& Marfai, M.A. (2017) The perception of stakeholders on regional transformation on the outskirts of Yogyakarta City, Indonesia. Geojournal, 83(5), 83-91

Goodchild, M. F. (2009) Geographic information systems and science: today and tomorrow. Journal Annals of GIS, 15 .

Govers, G., Takken, I. \& Helming, K. (2000) Soil roughness and overland flow. Agronomie, EDP Sciences, 20 (2), 131-146.

Győri, M. M., Haidu, I., \& Humbert, J. (2016). Deriving the floodplain in rural areas for high exceedance Probability Having limited data source. Environmental Engineering and Management Journal, 15, 18791887. DOI:10.30638/eemj.2016.201.

Hadisusanto, N. (2011) Aplikasi Hidrologi. Yogyakarta: Yogya Mediautama.

Idham, N. C. (2018) Riverbank Settlement and Humanitarian Architecture, The Case of Mangunwijaya's Dwellings and 25 Years After, Code River, Yogyakarta, Indonesia. Journal of Architecture and Urbanism, 42 (2), 177-187.

Ivan, K. (2015). The spatio-temporal analysis of impervious surfaces in Cluj-Napoca, Romania. Geographia Technica, 10 (2), 50-58.

Jha, A. K., Bloch, R. \& Lamond, J. (2012) Kota dan Banjir, Panduan Pengelolaan Terintegrasi untuk Resiko Banjir Perkotaan di Abad 21. Washington: The World Bank.

Johnston, R. J. (1981) The Dictionary of Human Geography. London: Basil Backwell Publisher Limited

Karaoui, I., Arioua, A., and Idrisi A E A (2016) Flood Inundation Mapping of Risk Zones in the Future Flood Events in Alfet River-Oued Al Abid Watershed-Using GIS Techniques and HEC-RAS Model. ATINER'S Conference Paper Series, No: ERT2016-2111

Kim, V., Tantanee, S., Suparta, W. (2020) GIS-based flood hazard mapping using HEC-RAS model: a case study of lower Mekong river, Cambodia. Geographia Technica, 15 (1), 16-26. DOI: 10.21163/GT_2020.151.02

Kodoatie, R. J. \& Sugiyanto (2002) BANJIR: Beberapa Penyebab dan Metode Pengendaliannya dalam Perspektif Lingkungan. Yogyakarta: Pustaka Pelajar.

Kusumastuti, C., Sudjarwo, P., Christhie, M. \& Krisna, T. (2019) Intensity-Duration-Frequency (IDF) Curve and the Most Suitable Method to Determine Flood Peak Discharge in Upper Werba Sub-Watershed. Civil Engineering Dimension Journal, 21 (2), 70-75.

Marfai, M. A. (2003) Pemodelan Banjir pada Kali Banjir Kanal Barat. Forum Geografi, 17 (1), 39-50.

Marfai, M. A. \& Sekaranom, A. B. (2012) SIG dan aplikasinya untuk analisis bahaya banjir. Proc. Seminar penginderaan jauh \& SIG, 292-300. UMS press. issn:978-979-636-137-3

McGrane, S.J. (2016) Impacts of urbanisation on hydrological and water quality dynamics, and urban water management: a review. Hydrological Sciences Journal, 61 (13), 2295-2311.

Meng, X., Zhang, M., Wen, J., Du, S., Xu, H., Wang, L. \& Yang, Y. (2019) A Simple GIS-Based Model for Urban Rainstorm Inundation Simulation. Journal of Sustainability MDPI, 11.

Miller, S. (1994) Handbook for Agrohydrology. Chatam, UK: Natural Reasources Institute Available from: http://www.nzdl.org/ [Accessed 14th November 2019].

Nusit, K., Tantanee, S., Subsomboon, K., Leungvichcharoen, S., Yiemwattana, S. (2019) The design of flood protection along Nan river, Phitsanulok Province, Thailand. Geographia Technica, 15, Special Issue, 129137. DOI: 10.21163/GT_2019.141.26 
Prayitno, B. (2018) Co-habitation Space: A Model for Urban Informal Settlement Consolidation for the Heritage City of Yogyakarta, Indonesia. Journal of Asian Architecture and Building Engineering, 16 (3), 527-534.

Rachmawati, R., Rijanta, R., Subanu \& Leksono, P. (2004) Peranan Kampus sebagai Pemicu Urbanisasi Spasial di Pinggiran Kota Yogyakarta. Majalah Geografi Indonesia, 18 (1), 45-46.

Samanta, S., Pal, D. K. \& Palsamanta, B. (2017) Flood susceptibility analysis through remote sensing, GIS and frequency ratio model. Journal of Applied Water Science, 8 (66).

Silva, F.V., Bonuma, N.B. \& Uda, P.K. (2014) Flood Mapping in Urban Area Using HEC-RAS Model Supported by GIS. $6^{\text {th }}$ International Conference $n$ Flood Management, Sao Paulo Brazil Available from: https://pdfs.semanticscholar.org/d841/024eab916629c07efd988bcb5093d265ecfa.pdf [Accessed 14th November 2019].

Suprayogi, S., Marfai, M. A., Cahyadi, A., Latifah, R. \& Fatchurohman, H. (2019) Analyzing the characteristics of domestic wastes in Belik river, Yogyakarta. Asean Journal on Science and Technology for Development, 36 (3), 97-102

Suradi \& Bakti, S. (2004) Efisiensi Pemanfaatan Lahan Perkotaan melalui Pengembangan Pengisian di Yogyakarta. Jurnal Manusia dan Lingkungan, 11 (1).

Suripin (2002) Pelestarian Sumberdaya Tanah dan Air. Yogyakarta: ANDI.

Tomaszewski, B., Judex, M., Szarsynski, J., Radestock, C. \& Wirkus, L. (2015) Geographic Information Systems for Disaster Response: A Review. Journal of Homeland Security\& Emergency Management, !2 (3).

US Army Corps of Engineers (1987) The Hydrologic Engineering Center's Activities in Watershed Modeling Available from: https://www.hec.usace.army.mil/publications/TechnicalPapers/TP-116.pdf [Accessed 14th November 2019].

US Army Corps of Engineers (2010a) HEC-RAS: River Analysis System. Applications Guide Book Available from: https://www.hec.usace.army.mil [Accessed 6th November 2019].

US Army Corps of Engineers (2010b) HEC-RAS: River Analysis System. User's Manual Available from: https://www.hec.usace.army.mil/ [Accessed 6th November 2019].

Xie, Y., Bie, Q. \& He, C. (2017) Human settlement andchanges in the distribution of river systems in the Minqin Basin over the past 2000 years in Nothwest China. Journal of Ecosystem Health and Sustainability, 3. 